\title{
JEKK
}

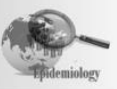

\section{Hubungan antara Pola Asuh Keluarga dengan Kejadian Balita Stunting pada Keluarga Miskin di Palembang}

\author{
Febriani Dwi Bella*, Nur Alam Fajar*, Misnaniarti* \\ *Fakultas Kesehatan Masyarakat, Universitas Sriwijaya, Indralaya Ogan Ilir, Sumatera Selatan
}

\begin{abstract}
Background: Stunting is a result of a malnutrition state that accumulates for an extended time and is a threat to the future of Indonesian children. The incidence of toddler's stunting is indirectly related to the role of parenting in the family, namely feeding, nurturing, hygiene and getting health services. The aim of the study was to analyze the correlation of parenting to the incidence of toddler's stunting on poor families in Palembang.
\end{abstract}

Methods: This research was an observational study which using a quantitative approach with a Cross Sectional Study design on March 2019. Data samples of 100 mothers who had children aged 24-59 months from poor families in Palembang were chosen by proportional random sampling.

Result: The results showed that the proportion of toddler's stunting in poor families in Palembang was $29 \%$. The results of bivariate analysis showed that there was a relationship between feeding habits $(\mathrm{p}=0,000)$; parenting habits $(\mathrm{p}=0.001)$; hygiene habits $(\mathrm{p}=0.021)$; and the habit of getting health services $(p=0,000)$ with the incidence of stunting for toddlers.

Conclusion : Normal height (not stunting) toddlers have parenting habits such as feeding habits, nurturing habits, hygiene habits and the habit of getting health services better than stunting toddlers in the same economic backgrounds family.

Keywords: stunting; parenting; toddler; hygiene.

*Penulis korespondensi, mimikaiarsha@gmail.com 


\section{Pendahuluan}

Stunting merupakan salah satu permasalahan status gizi pada balita yang digambarkan sebagai bentuk kegagalan pertumbuhan akibat gizi buruk dan kesehatan selama periode prenatal dan postnatal. ${ }^{1}$ Stunting muncul sebagai akibat dari keadaan kekurangan gizi yang terakumulasi dalam waktu yang cukup lama sehingga akan lebih terlihat manifestnya secara fisik di usia $24-59$ bulan. Dalam prosesnya, stunting dapat mengganggu perkembangan anak dari tahap awal konsepsi sampai tahun keempat kehidupan sebagai penentu penting pertumbuhan anak dan berpengaruh terhadap tingkat kecerdasannya. Anak yang mengalami stunting memiliki risiko 9 kali lebih besar memiliki nilai IQ di bawah rata-rata bila dibandingkan dengan anak yang tidak mengalami stunting. ${ }^{2}$ Stunting pada balita perlu mendapatkan perhatian khusus dikarenakan dapat menghambat perkembangan fisik dan mental pada anak. Stunting akan menjadi faktor risiko meningkatnya angka kematian, kemampuan kognitif, dan rendahnya perkembangan motorik serta ketidakseimbangan fungsi-fungsi tubuh. Stunting juga berhubungan dengan meningkatnya risiko penurunan kemampuan intelektual, produktivitas dan peningkatan risiko penyakit degeneratif di masa yang akan datang. Anak dengan stunting akan cenderung lebih rentan terhadap penyakit infeksi, sehingga memperbesar risiko mengalami penurunan kualitas belajar. ${ }^{3}$

Dari risiko - risiko yang telah disebutkan diatas, stunting merupakan ancaman bagi masa depan anak-anak di Indonesia. Puncak pertumbuhan penduduk produktif (bonus demografi) di Indonesia diproyeksikan terjadi pada tahun 2013. Namun hal tersebut akan siasia dan justru akan menjadi beban negara apabila tingginya prevalensi balita stunting di Indonesia tidak diperbaiki sekarang juga. ${ }^{4}$ Prevalensi stunting di Indonesia secara nasional menurut Riset Kesehatan Dasar Tahun 2013 sebesar 37,2\%, yang berarti mengalami peningkatan dari tahun 2010 yaitu sebesar $35,6 \%$. Hal ini menunjukkan bahwa prevalensi stunting di Indonesia lebih tinggi daripada negara lain di Asia Tenggara, seperti Myanmar
(35\%), Vietnam (23\%), dan Thailand (16\%). ${ }^{5}$ Berbagai upaya telah dilakukan oleh Pemerintah khususnya Kementerian Kesehatan RI sehingga dapat menekan angka stunting menjadi $30,8 \%$ dan sudah mencapai target RPJMN tahun 2019 yaitu sebesar 32\%. ${ }^{6}$ Namun hal ini tidak menyurutkan upaya pemerintah bahwa stunting masih menjadi permasalahan utama gizi yang harus diselesaikan mengingat Indonesia menduduki peringkat kelima dengan angka stunting tertinggi di dunia serta untuk mencapai target Global Prevalensi Stunting WHO sebesar 20,2\%. ${ }^{4}$ Data Riskesdas 2013 menyebutkan bahwa prevalensi balita pendek dan sangat pendek di Kota Palembang sebesar 27,4\%. Permasalahan stunting balita di Kota Palembang menduduki posisi teratas dibandingkan dengan permasalahan gizi KEP lain yang dialami oleh balita. ${ }^{7}$

Permasalahan stunting dipengaruhi oleh banyak faktor. Dalam The United Nation Children Fund, digambarkan bahwa faktor yang mempengaruhi status gizi secara langsung adalah asupan gizi dan keadaan penyakit infeksi. ${ }^{8}$ Apabila asupan gizi makin baik maka semakin baik juga status gizi serta imunitas akan semakin tinggi sehingga tidak mudah terkena penyakit. Dalam keadaan asupan gizi yang tidak baik, maka akan sangat rentan terkena penyakit terutama penyakit infeksi sehingga akan berujung pada masalah gizi. Pada konsep ini juga disebutkan bahwa status gizi juga dipengaruhi secara tidak langsung oleh berbagai faktor seperti ketersediaan pangan, pola asuh, sanitasi lingkungan dan pelayanan kesehatan. Ketersediaan pangan, sanitasi dan pelayanan kesehatan pada alurnya lebih dulu mempengaruhi asupan gizi dan penyakit infeksi sedangkan pola asuh selain melalui alur tersebut juga dapat secara vertikal langsung mempengaruhi status gizi. Sehingga pola asuh perlu untuk diperhatikan dan tidak dapat diabaikan dalam upaya peningkatan status gizi terutama pada balita. Faktor lingkungan yang menyangkut aspek alam, sosial maupun binaan merupakan faktor tidak langsung yang mempengaruhi status gizi. Berbagai penelitian menyebutkan status gizi dapat disebabkan oleh kondisi medis, status sosial ekonomi keluarga, dan sosial budaya. ${ }^{9}$ 
Faktor pola asuh yang tidak baik dalam keluarga merupakan salah satu penyebab timbulnya permasalahan gizi. Pola asuh meliputi kemampuan keluarga untuk menyediakan waktu, perhatian dan dukungan dalam memenuhi kebutuhan fisik, mental dan sosial dari anak yang sedang tumbuh dalam keluarga. ${ }^{10}$ Pola asuh terhadap anak dimanifestasikan dalam beberapa hal berupa pemberian ASI dan makanan pendamping, rangsangan psikososial, praktek kebersihan/hygiene dan sanitasi lingkungan, perawatan anak dalam keadaan sakit berupa praktek kesehatan di rumah dan pola pencarian pelayanan kesehatan. ${ }^{11}$ Kebiasaan yang ada didalam keluarga berupa praktik pemberian makan, rangsangan psikososial, praktik kebersihan/hygiene, sanitasi lingkungan dan pemanfaatan pelayanan kesehatan mempunyai hubungan yang signifikan dengan kejadian stunting anak usia $24-59$ bulan. $^{12}$

Dari keadaan tersebut dapat dilihat bahwa pola asuh keluarga berperan besar terhadap status gizi anak. Hal ini terlihat pada adanya fakta bahwa masalah gizi buruk/kurang tidak selalu terjadi pada keluarga miskin atau yang tinggal di lingkungan miskin. Dengan kata lain bahwa balita dengan keadaan gizi baik juga ditemukan pada keluarga miskin/marginal. Gizi buruk dapat terjadi pada anak manapun yang tidak secara mutlak dipengaruhi oleh kemampuan ekonomi keluarga. Hal ini mengindikasikan bahwa anak yang berasal dari keluarga dengan kemampuan ekonomi tinggi juga dapat mengalami gizi buruk. Dan sebaliknya pada keluarga dengan perekonomian rendah masih dapat dijumpai anak dengan status gizi yang baik.

Adanya penyebaran permasalahan gizi terutama stunting yang tidak merata menyebabkan adanya kawasan dengan kejadian stunting yang rendah di wilayah dengan tingkat kemiskinan yang tinggi. Data dari Dinas Sosial Kota Palembang menyebutkan bahwa jumlah keluarga penerima Program Keluarga Harapan $(\mathrm{PKH})$ sebagai indikator tingkat kemiskinan di Kota Palembang sebesar 53.678 Keluarga Penerima Manfaat (KPM). Program Keluarga Harapan adalah program pemberian bantuan sosial bersyarat kepada Keluarga Penerima Manfaat sebagai upaya percepatan penanggulangan kemiskinan yang bertujuan untuk mengurangi beban pengeluaran serta memberikan nutrisi yang lebih seimbang secara tepat sasaran dan tepat waktu. ${ }^{13}$ Dari data tersebut menunjukkan bahwa penyebaran keluarga miskin di Kota Palembang tidak sejalan dengan jumlah kejadian stunting. Hal tersebut menggambarkan bahwa di dalam keluarga miskin di Kota Palembang persentase jumlah balita dengan status gizi baik cukup tinggi ditunjukkan dengan angka kejadian stunting yang rendah.

\section{Metode}

Penelitian ini merupakan penelitian observasional yang dilakukan menggunakan pendekatan kuantitatif dengan desain Studi Cross Sectional yang dilakukan pada bulan Maret 2019 di Kota Palembang.

Populasi penelitian ini adalah seluruh ibu balita usia 24 - 59 bulan di wilayah Kota Palembang. Sampel penelitian sesuai dengan kriteria inklusi yaitu ibu balita usia $24-59$ bulan dari keluarga miskin yang tinggal di Kota Palembang. Kriteria keluarga miskin yang digunakan dalam penelitian ini adalah keluarga penerima Program Keluarga Harapan (PKH) dari pemerintah berdasarkan Data Dinas Sosial Kota Palembang Tahun 2018. Berdasarkan kriteria tersebut didapatkan jumlah sampel sebesar 100 ibu balita.

Data yang diambil dalam penelitian ini adalah informasi tentang kebiasaan pemberian makan, kebiasaan pengasuhan, kebiasaan kebersihan dan kebiasaan mendapatkan pelayanan kesehatan yang diperoleh dengan wawancara menggunakan kuisioner. Sedangkan pengukuran tinggi badan balita menggunakan alat ukur tinggi badan dalam satuan centimeter sesuai dengan standar dari Kementerian Kesehatan RI.

\section{Hasil}

Tabel 1.Distribusi Frekuensi Kejadian Stunting Balita

\begin{tabular}{|c|c|c|}
\hline Kejadian Stunting & $\mathrm{n}$ & $\%$ \\
\hline Stunting & 29 & 29 \\
\hline Normal & 71 & 71 \\
\hline Jumlah & 100 & 100 \\
\hline
\end{tabular}


Tabel 2.Distribusi Frekuensi Pola Asuh

\begin{tabular}{lcc}
\hline \multicolumn{1}{c}{ Variabel } & $\mathrm{n}$ & $\%$ \\
\hline Kebiasaan Pemberian Makan & & \\
- Kurang Baik & 19 & 19,0 \\
- Baik & 81 & 81,0 \\
\hline Kebiasaan Pengasuhan & & \\
- Kurang Baik & 17 & 17,0 \\
- Baik & 83 & 83,0 \\
\hline Kebiasaan Kebersihan & & \\
- Kurang Baik & 7 & 73,0 \\
- Baik & 93 & 93,0 \\
\hline Kebiasaan Mendapatkan & & \\
Pelayanan Kesehatan & & \\
- Kurang Baik & 16 & 16,0 \\
- Baik & 84 & 84,0 \\
\hline
\end{tabular}

Tabel 3. Hubungan Pola Asuh dengan Kejadian Stunting Balita

\begin{tabular}{|c|c|c|c|c|}
\hline \multirow{3}{*}{$\begin{array}{l}\text { Pola } \\
\text { Asuh }\end{array}$} & \multicolumn{2}{|c|}{ Kejadian Stunting } & \multirow[b]{2}{*}{ Total } & \multirow{3}{*}{$\begin{array}{c}p- \\
\text { valu } \\
e\end{array}$} \\
\hline & $\begin{array}{c}\text { Stuntin } \\
\mathrm{g}\end{array}$ & Normal & & \\
\hline & $\mathrm{n} \%$ & $\%$ & $\%$ & \\
\hline
\end{tabular}

\begin{tabular}{llllllll}
\hline Kebiasaan Pemberian Makan & & & \\
Kurang & 13 & 68,4 & 6 & 31,6 & 19 & 100 & 0,000 \\
Baik & & & & & & & \\
Baik & 16 & 19,8 & 65 & 80,2 & 81 & 100 & \\
\hline
\end{tabular}

Kebiasaan Pengasuhan

$\begin{array}{llllllll}\text { Kurang } & 11 & 64,7 & 6 & 35,3 & 17 & 100 & 0,001\end{array}$

Baik

$\begin{array}{lllllll}\text { Baik } & 18 & 21,7 & 65 & 78,3 & 83 & 100\end{array}$

\begin{tabular}{llllllll}
\hline Kebiasaan Kebersihan & & & & \\
Kurang & 5 & 71,4 & 2 & 28,6 & 7 & 100 & 0,021 \\
Baik & & & & & & & \\
Baik & 24 & 25,8 & 69 & 74,2 & 93 & 100 & \\
\hline
\end{tabular}

Kebiasaan Mendapatkan Pelayanan Kesehatan

$\begin{array}{llllllll}\text { Kurang } & 11 & 68,8 & 5 & 31,2 & 16 & 100 & 0,000\end{array}$

Baik

$\begin{array}{lllllll}\text { Baik } & 18 & 21,4 & 66 & 78,6 & 84 & 100\end{array}$

\begin{tabular}{llllllll}
\hline Jumlah & 29 & 29,0 & 71 & 71,0 & 100 & 100
\end{tabular}

\section{Pembahasan}

\section{Kebiasaan Pemberian Makan}

Berdasarkan hasil analisis bivariat dalam penelitian ini menunjukkan dari seluruh responden ibu dengan kebiasaan pemberian makan yang kurang baik terhadap balitanya sebagian besar memiliki balita stunting yaitu sebesar 68,4\%. Sedangkan dari seluruh responden ibu dengan kebiasaan pemberian makan yang baik, yang memiliki balita stunting hanya sebesar 19,8\%. Berdasarkan analisis bivariat diperoleh $p$-value $=0,000 \quad(\mathrm{p}<0,05)$, yang menunjukkan bahwa ada hubungan yang signifikan antara kebiasaan pemberian makan dengan kejadian stunting balita dari keluarga miskin dengan $\mathrm{OR}=8,802$; $\mathrm{CI} 95 \%=2,897$ 26,743. Secara statistik menunjukkan bahwa ibu dengan kebiasaan pemberian makan yang kurang baik pada balitanya mempunyai kecenderungan 8,8 kali lebih besar untuk memiliki balita stunting dibandingkan ibu dengan kebiasaan pemberian makan yang baik pada balitanya. Hasil penelitian ini sejalan dengan hasil penelitian yang dilakukan oleh Rahmayana, dkk (2014) di Kota Makassar, yang menyebutkan bahwa praktek pemberian makan dalam kategori baik ada pada 55,6\% anak dengan tinggi badan normal dan adanya hubungan yang signifikan antara praktek pemberian makan dengan kejadian stunting anak usia $24-59$ bulan $(p=0,007)$.

Pemberian makan dengan cara yang sehat, pemberian makan bergizi dan mengatur porsi yang dihabiskan akan meningkatkan status gizi anak. Makanan yang baik untuk bayi dan balita harus memenuhi syarat-syarat kecukupan energi dan zat gizi sesuai umur, pola menu seimbang dengan bahan makanan yang tersedia, kebiasaan dan selera makan anak, bentuk dan porsi makanan yang disesuaikan pada kondisi anak dan memperhatikan kebersihan perorangan dan lingkungan. ${ }^{11}$ Ini sejalan dengan satu penelitian yang menyebutkan praktek pemberian makan oleh ibu pada kelompok anak normal (tidak stunting) lebih baik dibandingkan pada kelompok anak stunting. Praktek pemberian makan tersebut antara lain meliputi frekuensi pemberian makan, pemberian makanan selingan, pertimbangan pemilihan jenis, pemberian makanan lengkap, penentuan waktu dan cara pemberian makan. Praktek pemberian makan yang kurang baik mengakibatkan anak tidak memperoleh asupan gizi seimbang dan secara kumulatif mengakibatkan gangguan pertumbuhan anak. ${ }^{14}$

\section{Kebiasaan Pengasuhan}

Hasil analisis menunjukkan dari seluruh responden ibu dengan kebiasaan pengasuhan yang kurang baik terhadap balitanya sebagian 
besar memiliki balita stunting yaitu sebesar $64,7 \%$. Sedangkan dari seluruh responden ibu dengan kebiasaan pengasuhan yang baik, yang memiliki balita stunting hanya sebesar $21,7 \%$. Berdasarkan analisis bivariat didapatkan $p$ value $=0,001 \quad(\mathrm{p}<0,05)$, yang menunjukkan bahwa ada hubungan yang signifikan antara kebiasaan pengasuhan dengan kejadian stunting balita dari keluarga miskin dengan $\mathrm{OR}=6,620 ; \quad \mathrm{CI} 95 \%=2,153-20,359$. Hal ini menunjukkan secara statistik bahwa ibu dengan kebiasaan pengasuhan yang kurang baik pada balitanya mempunyai kecenderungan 6,62 kali lebih besar untuk memiliki balita stunting dibandingkan ibu dengan kebiasaan pengasuhan yang baik pada balitanya. Hasil penelitian ini sejalan dengan hasil penelitian Turnip (2008) di Kecamatan Sidikalang yang menyebutkan bahwa adanya perbedaan yang signifikan antara kebiasaan pola asuh terhadap status gizi anak. Anak dengan status gizi tidak baik mempunyai peluang 9 kali pada keluarga yang menerapkan kebiasaan pola asuh tidak baik dibandingkan anak pada keluarga dengan pola asuh yang baik. Pola pengasuhan merupakan hal yang penting dalam proses tumbuh kembang anak. Salah satu faktor yang mempengaruhi pertumbuhan dan perkembangan anak adalah adanya faktor psikososial yang didalamnya mencakup hal penting dalam kehidupan anak yaitu pentingnya stimulasi dalam pengasuhan. Pola pengasuhan yang baik merupakan gambaran adanya interaksi positif anak dengan pengasuh utama yang berperan dalam perkembangan emosi dan psikologis anak sehingga menciptakan tumbuh kembang anak yang normal. ${ }^{15}$ Peran orang tua sedini mungkin akan menjalin rasa aman pada anaknya. Hal tersebut diwujudkan dengan kontak fisik dan psikologis sejak anak lahir hingga dalam proses tumbuh kembangnya. Kurangnya kasih sayang orang tua di tahun-tahun pertama berdampak negatif pada tumbuh kembang anak baik fisik, mental, maupun sosial emosi. Kasih sayang orang tua akan menciptakan ikatan yang erat (bonding) dan kepercayaan dasar (basic trust). ${ }^{16}$

Hubungan yang erat, mesra dan selaras antara orang tua dan anak merupakan syarat mutlak untuk menjamin tumbuh kembang yang selaras, baik fisik, mental maupun psikososial.
Ibu yang memberikan rangsangan psikososial yang baik pada anak berpengaruh positif pada status gizi anak. Hal ini sesuai dengan penelitian mengenai positive deviance pada keluarga miskin yang mengungkap bahwa asuhan psikososial berupa keterikatan antara ibu dan anak menjadi faktor penting dalam tumbuh kembang anak. Kondisi psikososial yang buruk dapat mempengaruhi pemanfaatan zat gizi dalam tubuh, sebaliknya hormon pertumbuhan dirangsang kondisi psikososial yang baik. Secara tidak langsung asuhan psikososial berkaitan dengan asuhan gizi dan kesehatan yang berpengaruh positif pada status gizi, tumbuh dan kembang. ${ }^{17}$

\section{Kebiasaan Kebersihan}

Hasil analisis bivariat menunjukkan dari seluruh responden ibu dengan kebiasaan kebersihan yang kurang baik terhadap balitanya sebagian besar memiliki balita stunting yaitu sebanyak 5 responden $(71,4 \%)$. Sedangkan dari seluruh responden ibu dengan kebiasaan kebersihan yang baik, yang memiliki balita stunting hanya sebesar $25,8 \%$. Berdasarkan analisis bivariat diperoleh $p$ value $=0,021 \quad(\mathrm{p}<0,05)$, yang menunjukkan bahwa ada hubungan yang signifikan antara kebiasaan kebersihan dengan kejadian stunting balita dari keluarga miskin dengan $\mathrm{OR}=7,188$; CI95\%=1,307-39,515. Hal ini menunjukkan secara statistik bahwa ibu dengan kebiasaan kebersihan yang kurang baik pada balitanya memiliki kecenderungan 7,19 kali lebih besar untuk memiliki balita stunting dibandingkan ibu dengan kebiasaan kebersihan yang baik pada balitanya. Hasil penelitian ini juga sejalan dengan penelitian Rahmayana (2014) yang menunjukkan adanya hubungan yang signifikan antara praktek kebersihan/hygiene dengan kejadian stunting anak $(\mathrm{p}=0,000)$. Yudianti (2016) menyebutkan bahwa ada hubungan antara praktek kebersihan diri dengan kejadian stunting dengan $\mathrm{p}=0,016$ dan $\mathrm{OR}=3,42$, diartikan bahwa praktek kebersihan diri yang kurang baik memiliki risiko 3,42 kali lebih tinggi untuk terjadi stunting dibandingkan yang memiliki praktek kebersihan yang baik.

Kebersihan diri maupun lingkungan berperan penting dalam tumbuh kembang anak. Kebersihan tubuh, makanan dan lingkungan 
berperan besar dalam pemeliharaan kesehatan yang akan mencegah penyakit-penyakit infeksi sebagai faktor penyebab turunnya status gizi anaknya. Kebiasaan kebersihan harus sesuai dengan syarat kesehatan dalam menjaga kesehatan tubuh dengan mandi dua kali sehari, rambut, tangan, kaki dan pakaian harus bersih, menggosok gigi, menjaga kebersihan diri dan lingkungan. Kebersihan diri yang tidak baik akan memudahkan terjadinya penyakit infeksi saluran pencernaan seperti diare dan cacingan. Sedangkan kebersihan lingkungan berkaitan dengan penyakit saluran pernafasan, pencernaan dan penyakit infeksi lainnya. ${ }^{18}$ Kebersihan tubuh, makanan dan lingkungan berperan besar dalam pemeliharaan kesehatan yang akan mencegah penyakit-penyakit infeksi sebagai faktor penyebab turunnya status gizi anak. $^{16}$

\section{Kebiasaan Mendapatkan Pelayanan Kesehatan}

Hasil analisis menunjukkan dari seluruh responden ibu dengan kebiasaan mendapatkan pelayanan kesehatan yang kurang baik untuk balitanya sebagian besar memiliki balita stunting yaitu sebanyak 11 responden $(68,8 \%)$. Sedangkan dari seluruh responden ibu dengan kebiasaan mendapatkan pelayanan kesehatan yang baik untuk balitanya, yang memiliki balita stunting hanya sebesar 21,4\%. Berdasarkan analisis bivariat diketahui $p$ value $=0,000(\mathrm{p}<0,05)$, ini menunjukkan bahwa ada hubungan yang signifikan antara kebiasaan mendapatkan pelayanan kesehatan dengan kejadian stunting balita dari keluarga miskin dengan OR=8,067; CI95\%=2,482-26,216. Hal ini menunjukkan secara statistik bahwa ibu dengan kebiasaan mendapatkan pelayanan kesehatan yang kurang baik bagi balitanya mempunyai kecenderungan 8,07 kali lebih besar untuk memiliki balita stunting dibandingkan dengan kebiasaan mendapatkan pelayanan kesehatan yang baik untuk balitanya.

Hal ini senada dengan hasil penelitian Panjaitan (2011) yang menyebutkan bahwa terdapat hubungan status gizi dengan pola asuh menurut praktek kesehatan $(\mathrm{p}=0,039)$. Penelitian Turnip (2008) juga menyatakan bahwa adanya perbedaan yang signifikan pada kebiasaan memperoleh pelayanan kesehatan terhadap status gizi anak $(\mathrm{p}=0,000)$, bahwa anak yang memiliki status gizi tidak baik mempunyai peluang 11 kali pada keluarga yang pelayanan kesehatannya tidak baik dibandingkan dengan anak pada keluarga yang mendapatkan pelayanan kesehatan yang baik.

Permasalahan gizi dipengaruhi langsung oleh asupan gizi dan diperburuk oleh paparan penyakit infeksi pada balita. Kejadian infeksi penyakit pada anak berkaitan erat dengan akses dan pemanfaatan pelayanan kesehatan. Kebiasaan dalam upaya mendapatkan pelayanan kesehatan mencakup cara ibu untuk mengakses pelayanan kesehatan anak dengan memberikan imunisasi yang lengkap, pengobatan penyakit dan bantuan tenaga profesional dalam menjaga kesehatan anak. Hal tersebut sangat berperan dalam peningkatan status gizi anak dimana ibu berupaya memanfaatkan pelayanan kesehatan yang ada untuk memperoleh informasi kesehatan yang benar. Upaya peningkatan pemanfaatan pelayanan kesehatan yaitu menambah informasi kesehatan pada ibu dengan berbagai kegiatan misalnya penyuluhan gizi dan kesehatan serta konseling gizi bagi ibu dengan balita yang mengalami permasalahan gizi. Penelitian menyebutkan adanya perbedaan pengetahuan yang signifikan pada ibu antara sebelum dan sesudah konseling gizi ${ }^{19,20}$

\section{Kesimpulan}

Pola asuh dalam keluarga berupa kebiasaan pemberian makan, kebiasaan pengasuhan, kebiasaan kebersihan dan kebiasaan mendapatkan pelayanan kesehatan berhubungan dengan kejadian stunting balita. Permasalahan gizi balita stunting tidak mutlak terjadi pada keluarga miskin tetapi lebih disebabkan oleh peranan pola asuh yaitu kebiasaan pemberian makan, kebiasaan pengasuhan, kebiasaan kebersihan dan kebiasaan mendapatkan pelayanan kesehatan yang baik dalam keluarga miskin dapat mengurangi kecenderungan balita untuk mengalami stunting. 


\section{Ucapan Terimakasih}

Terima kasih pada semua pihak yang telah membantu khususnya kepada Dinas Kesehatan Kota Palembang dan ibu serta balita yang bersedia turut serta dalam penelitian ini.

\section{Daftar Pustaka}

1. Milman, A., Frongillo, E. A., Onis, M., Hwang, J. 2005. Differential Improvement among Countries in Child Stunting is Associated with Long-Term Development and Specific Interventions. The Journal of Nutrition, 135(August 2004) : 1415-1422.

2. Arfines, P. P. and Puspitasari, F. D. 2017. Hubungan Stunting dengan Prestasi Belajar Anak Sekolah Dasar di Daerah Kumuh Kotamadya Jakarta Pusat. Buletin Penelitian Kesehatan, 45(1) : 45-52.

3. Indrawati, S. 2016. Hubungan Pemberian Asi Esklusif Dengan Kejadian Stunting Pada Anak Usia 2-3 Tahun Di Desa Karangrejek Wonosari Gunungkidul (Skripsi).Universitas Aisyiyah Yogyakarta.

4. Badan Litbang Kesehatan. 2018. Stunting dan TBC Mengancam Masa Depan Indonesia. www.litbang.kemkes.go.id. Diakses tanggal 23 November 2018.

5. Millennium Challenge Account Indonesia. 2014. Backgrounder : stunting dan masa depan indonesia. www.mcaindonesia.go.id. Diakses tanggal 10 November 2018.

6. Kementerian Kesehatan RI. 2018. Hasil Utama Riskesdas 2018. Jakarta.

7. Dinas Kesehatan Kota Palembang. 2017. Laporan Hasil Operasi Timbang 2017. Palembang.

8. UNICEF. 1998. Third Report on the World Nutrition Situation: A Report Compiled From Information Available to the ACC/SCN.

9. Handayani, K. O. W. and Prameswari, G. N. 2012. Daerah Positive Deviance Sebagai Rekomendasi Model Perbaikan Gizi. Jurnal Kesehatan Masyarakat, 7(2) : 102-109.
10. Engle, P. L., Menon, P. and Haddad, L. 1999. Care and Nutrition: Concepts and Measurement. World Development. International Food Policy Research Institute.

11. Panjaitan, R. 2011. Pola Asuh Ibu dan Status Gizi Anak Balita di Kecamatan Pollung Kabupaten Humbang Hasundutan Tahun 2011 (Thesis). Universitas Sumatera Utara.

12. Rahmayana. 2014. Hubungan Pola Asuh Ibu dengan Kejadian Stunting Anak Usia 24-59 bulan di Posyandu Asoka II Wilayah Pesisir Kelurahan Barombong Kecamatan Tamalate Kota Makasar Tahun 2014. Al Sihah : Public Health Science Journal, 6(2) : 424-436.

13. Kemensos RI. 2018. Bantuan Pangan Non Tunai.https://www.kemsos.go.id/page/bant uan-pangan-non-tunai. Diakses tanggal 3 November 2018.

14. Astari, L. D., Nasoetion, A. and Dwiriani, C. 2005. Hubungan Karakteristik Keluarga, Pola Pengasuhan dan Kejadian Stunting Anak Usia 6-12 Bulan. Media Gizi dan Keluarga, 29(2) : 40-46.

15. Turnip, F. 2008. Pengaruh Positive Deviance pada Ibu dari Keluarga Miskin Terhadap Status Gizi Anak Usia 12-24 bulan di Kecamatan Sidikalang Kabupaten Dairi Tahun 2007 (Thesis). Universitas Sumatera Utara.

16. Soetjiningsih. 1995. Tumbuh Kembang Anak. Jakarta: Penerbit Buku Kedokteran EGC.

17. Zeitlin, M., Ghassemi, H., Mansour, M., Levine, R. A., Dillanneva, M., Carballo, M., Sockalingam, S. 1990. Positive Deviance in Child Nutrition: With Emphasis on Psychosocial and Behavioural Aspects and Implications for Development.

18. Lanita, U., Febry, F. and Mutahar, R. 2012. Gambaran Perilaku Positive Deviance Pada Ibu Dan Status Gizi Kecamatan Pemulutan Kabupaten Ogan Ilir. Ilmu Kesehatan Masyarakat, 3(1) : 24-34. 
19. Hestuningtyas, T. R. 2013. Pengaruh Konseling Gizi terhadap Pengetahuan, Sikap, Praktik Ibu dalam Pemberian Makan Anak dan Asupan Zat Gizi Anak Stunting Usia 1-2 Tahun di Kecamatan Semarang Timur (Skripsi). Universitas Diponegoro.
20. Yuliati, A. Soejoenoes, A., Suwondo, A., Anies, Kartasurya, M.I., 2017. Beberapa Faktor Risiko Gizi Kurang dan Gizi Buruk pada Balita 12-59 Bulan (Studi Kasus di Kota Pontianak). Jurnal Epidemiologi Kesehatan Komunitas, 2(1): 54-62. 